\title{
Kesiapsiagaan Masyarakat Terhadap Bencana Tanah Longsor Di Desa Sukawana
}

\author{
I Nengah Sumana ${ }^{1 *}$, Putu Indra Christiawan ${ }^{1}$, I Gede Budiarta ${ }^{1}$
}

${ }^{1}$ Program Studi Pendidikan Geografi, Jurusan Geografi, Universitas Pendidikan Ganesha, Indonesia

\author{
A R T I C L EI N F O \\ Article history: \\ Received 15 February \\ 2020 \\ Accepted 24 February \\ 2020 \\ Available online 30 \\ April 2020 \\ Kata Kunci: \\ Pengetahuan; \\ Kesiapsiagaan; Tanah \\ Longsor \\ Keywords: \\ Knowledge; \\ Preparedness; \\ Landslide
}

\begin{abstract}
A B S T R A K
Penelitian ini bertujuan untuk mengkaji pengetahuan masyarakat tentang bencana tanah longsor di Desa Sukawana, mengkaji kesiapsiagaan masyarakat terhadap bencana tanah longsor di Desa Sukawana dan menganalisis hubungan antara pengetahuan masyarakat tentang bencana tanah longsor dengan kesiapsiagaan masyarakat terhadap bencana tanah longsor di Desa Sukawana. Pengumpulan data menggunakan metode observasi, wawancara dan studi putaka. Data yang diperoleh dianalisis secara deskriptif kualitatif dan deskriptif kuantitatif menggunakan analisis statistic product moment, dilihat dari bidang ilmu yang digunakan untuk mengkaji yaitu geografi bencana yang dianalisis dengan pendekatan keruangan. Populasi dalam penelitian ini mencakup seluruh masyarakat yang sama-sama tinggal di daerah rawan longsor. Sampel area menggunakan teknik purposive sampling diambil empat dusun yaitu Dusun Kuta Dalem, Dusun Kubu Salya, Dusun Lateng, Dusun Sukawana. Sampel subjek diambil sejumlah 88 orang yang ditentukan dengan random sampling. Hasil penelitian menunjukkan bahwa pengetahuan
\end{abstract} masyarakat tentang bencana tanah longsor di Desa Sukawana secara umum terkategori sedang yaitu sebanyak 51\%. Kesiapsiagaan masyarakat terhadap bencana tanah longsor di Desa Sukawana secara umum terkategori kurang siap yaitu sebanyak 58\%. Uji statistik menunjukkan terdapat hubungan yang signifikan antara pengetahuan masyarakat tentang bencana tanah longsor dengan kesiapsiagaan masyarakat terhadap bencana tanah longsor di Desa Sukawana dengan nilai $r x y=0,228$ pada taraf signifikansi $5 \%$.

\begin{abstract}
A B S T R A C T
This research was conducted in Sukawana Village, Kintamani District, Bangli Regency. The aim of assessing community knowledge about landslides in Sukawana Village, assessing community preparedness for landslides in Sukawana Village, and analyzing the relationship between community knowledge about disasters landslides with community preparedness for landslides in Sukawana Village. Data collection uses observation, interviews, and study methods. The data obtained were analyzed descriptively qualitative and quantitative descriptive using statistical analysis of product-moment. Seen from the field of science used to study the disaster geography that is analyzed by a spatial approach. The population in this study includes all people who are equally living in areas prone to landslides. The area sample uses a purposive sampling technique taken four hamlets, namely Kuta Dalem Hamlet, Kubu Salya Hamlet, Lateng Hamlet, Sukawana Hamlet. Subject samples were taken as many as 88 people who were determined by random sampling. The results showed that public knowledge about landslides in Sukawana Village generally categorized as moderate, namely as much as $51 \%$. Community preparedness for landslides in Sukawana Village generally categorized as less ready at 58\%. Statistics test shows that there is a significant relationship between community knowledge about landslide disasters and community preparedness for landslides in Sukawana Village with a value of rxy $=0.228$ at the level of significance of $5 \%$.
\end{abstract}

Copyright (C) Universitas Pendidikan Ganesha. All rights reserved. 


\section{Pendahuluan}

Gunung Wilayah Indonesia termasuk daerah rawan terjadinya bencana, karena posisi Indonesia terletak pada pertemuan tiga lempeng yaitu lempeng Benua Australia, lempeng Benua Eurasia dan lempeng Samudera Pasifik. Tumbukan lempeng-lempeng tersebut menyebabkan zona penunjaman yang merupakan jalur gempa bumi dan membentuk undulasi di busur kepulauan dengan kemiringan terjal sampai sangat terjal (Setyari, 2012). Selain itu, Indonesia juga terletak di daerah tropis dengan curah hujan yang tinggi dan memiliki topografi yang bervariasi, faktor tersebut yang menyebabkan Indonesia rentan terhadap bencana tanah longsor.

Bali merupakan salah satu daerah yang memiliki potensi bencana tanah longsor, serta setiap tahun terjadi tanah longsor. Menurut Bappeda Bali dan PPLH UNUD tahun 2006 potensi bencana tanah longsor di Provinsi Bali seluas 85.121,55 hektar. Bencana tanah longsor seringkali terjadi pada daerah yang memiliki topografi tinggi, kabupaten yang memiliki topografi tinggi adalah Kabupaten Bangli yang berada pada ketinggian antara 100 - 2.152 meter dpl. Kabupaten Bangli terdiri dari 4 kecamatan yaitu Kecamatan Susut, Kecamatan Kintamani, Kecamatan Bangli dan Kecamatan Tembuku, dengan penyebaran curah hujan tertinggi $(2.500-3.500 \mathrm{~mm})$ di bagian utara lereng gunung batur dan dilihat dari tofografi wilayah bervariasi antar kecamatan, dengan kelerengan yanag paling curam pada wilayah Kecamatan Kintamani (Pemerintah Kabupaten Bangli, 2019). Faktor curah hujan yang paling tinggi dan tofografi yang curam tersebut yang menyebabkan Kecamatan Kintamani sebagai daerah yang paling rawan bencana tanah longsor di Kabuapaten Bangli.

Berdasarkan data Badan Penanggulangan Bencana Daerah Kabupaten Bangli tahun 2018 diketahui bahwa desa yang paling sering terjadi tanah longsor di Kecamatan Kintamani adalah Desa Songan B dan Desa Sukawana, yang mengalami jumlah kejadian tanah longsor sebanyak empat kali dari tahun 2012 s.d. 2018. Pada September 2017 pemerintah Kabupaten Bangli menjadikan Desa Songan B sebagai Kampung Siaga Bencana (KSB) yang sudah dilaksanakannya penyuluhan, pelatihan, simulasi, pengukuhan dan kegiatan lanjutan seperti pendirian lumbung sosial dan gardu sosial yang berlokasi di Desa Songan B (Pemerintah Kabupaten Bangli, 2017). Sehingga sebagian masyarakat sudah mengetahui memitigasi bencana khususnya tanah longsor. Desa dengan kejadian tanah longsor tinggi berikutnya yaitu Desa Sukawana, Desa Sukawana belum ada program tanggap bencana maka masyarakatnya belum mengetahui memitigasi bencana tanah longsor, disisi lain Desa Sukawana juga merupakan desa dengan jumlah penduduk terbanyak kedua di Kecamatan Kintamani dengan jumlah penduduk 5.160 pada sensus penduduk tahun 2016 (Disdukcapil Kabupaten Bangli, 2019)

Desa Sukawana terletak di daerah pegunungan dengan ketinggian $1.745 \mathrm{~m}$ dpl yang memiliki topografi bergelombang dengan kemiringan lereng yang beragam dari agak curam hingga sangat curam yang disusun oleh batuan gunungapi batur kelompok Buyan-Beratan yang terdiri dari tuff dan lahar (Suarsana, 2015). Desa Sukawana memiliki curah hujan yang tinggi karena berada di daerah tertingi di Kecamatan Kintamani.

Kerentanan gerakan tanah di Desa Sukawana termasuk dalam kategori menengah hingga tinggi yang menyebabkan Desa Sukawana sangat berpotensi terjadi longsor (Wulan. 2017). Hal ini juga di dukung oleh Peta Zona Kerentanan Gerakan Tanah Kabupaten Bangli Provinsi Bali ( Pusat Vulkanologi dan Mitigasi Bencana. 2017), menjelaskan bahwa keretanan gerakan tanah di Desa Sukawana termasuk dalam kategori tinggi. Frekuensi kejadian bencana tinggi hampir setiap tahun terjadi bencana tanah longsor di Desa Sukawana. Berdasarkan laporan Badan Penanggulangan Bencana Daerah Kabupaten Bangli (2018), tanah longsor di Desa Sukawana tercatat terjadi pada tahun 2012, 2016, 2017 dan 2018, dengan puncak tanah longsor terbesar terjadi pada tanggal 10 Februari 2017. 
Terjadinya bencana tanah longsor memberikan dampak negatif terhadap kerusakan kondisi lingkungan fisik dan masyarakat. Berikut ini merupakan dampak kejadian tanah longsor di Desa Sukawana dalam kurun waktu 10 tahun terakhir yang dapat dilihat pada Tabel 1.

Tabel 1. Dampak kejadian tanah longsor di Desa Sukawana

\begin{tabular}{cll}
\hline No & Tanggal Kejadian & Dampak Kejadian \\
\hline (1) & (2) & (3) \\
\hline 1. & 13 Maret 2012 & $\begin{array}{l}\text { 1 orang meninggal dan rusaknya lahan pertanian jeruk dan kopi sehingga } \\
\text { gagal panen. }\end{array}$ \\
\hline 2. & 21 Desember 2016 & $\begin{array}{l}\text { Tanah longsor menutup sebagian jalan di jalur Kintamani-Singaraja } \\
\text { tepatnya di wilayah penulisan Desa Sukawana }\end{array}$ \\
\hline 3. & 10 Februari 2017 & $\begin{array}{l}\text { 1 orang meninggal, 1 rumah rusak berat/hancur, 2 rumah terancam dan } \\
\text { 3 KK diungsikan. }\end{array}$ \\
\hline 4. & 28 Januari 2018 & $\begin{array}{l}\text { Jalan di Dusun Kubusalya tidak bisa dilalui kendaraan karena seluruh } \\
\text { badan jalan tertimbun material tanah, warga dari Dusun Kubusalya yang } \\
\text { hendak ke pusat Desa Sukawana menggunakan kendaraan hanya bisa } \\
\text { melalui jalan melingkar ke Desa Kutuh. Jarak yang ditempuh jika melalui } \\
\text { jalan melingkar panjang sekitar 10 kilometer }\end{array}$ \\
\hline
\end{tabular}

Sumber. Badan Penanggulangan Bencana Daerah Kabupaten Bangli, 2018

Dari dampak tanah longsor tersebut tidak menutup kemungkinan akan adanya tanah longsor susulan. Oleh karena itu, diperlukan kesiapsiagaan masyarakat untuk mengantisipasi bencana tanah longsor. Kesiapsiagaan merupakan salah satu bagian dari proses manajemen bencana dan di dalam konsep pengelolaan bencana yang berkembang saat ini, peningkatan kesiapsiagaan merupakan salah satu elemen penting dari kegiatan pengurangan risiko bencana yang bersifat pro-aktif, sebelum terjadinya suatu bencana.

Menurut LIPI-UNESCO/ISDR (2006), pengetahuan merupakan faktor utama dalam kesiapsiagaan. Kemungkinan pengetahuan masyarakat tentang bahaya tanah longsor di Desa Sukawana berpengaruh terhadap kesiapsiagaan dalam menghadapi bencana tanah longsor. Namun, masyarakat yang tinggal di daerah rawan terhadap bencana tanah longsor kemungkinan memiliki pengetahuan yang kurang. Hal ini dikarenakan belum adanya upaya peningkatan pengetahuan masyarakat tentang bahaya tanah longsor di Desa Sukawana baik dalam bentuk penyuluhan maupun sarana dan prasarana yang berkaitan. Berdasarkan latar belakang, maka tujuan penelitian ini adalah sebagai upaya identifikasi daerah yang berpotensi terjadi bahaya tanah longsor dengan cara meningkatkan kesiapsiagaan secara terpadu dan terarah agar dapat meminimalisasi kerugian yang ditimbulkan.

\section{Metode}

Penelitian ini adalah penelitian deskriptif. Penelitian deskriptif menunjukkan bahwa gejala yang diteliti dalam penelitian ini sudah ada tanpa dibuat oleh peneliti. Gejala yang dideskripsikan adalah pengetahuan dan kesiapsiagaan masyarakat terhadap bencana tanah longsor di Desa Sukawana. Selain itu juga mendeskripsikan hubungan antara pengetahuan tentang bencana tanah longsor dan kesiapsiagaan masyarakat terhadap bencana tanah longsor. Bidang ilmu yang digunakan untuk mengkaji yaitu geografi bencana yang dianalisis dengan pendekatan keruangan. Sampel area diambil sejumlah 4 dusun yang ditentukan dengan teknik purposive sampling yaitu Dusun Kuta Dalem, Dusun Kubu Salya, Dusun Lateng dan Dusun Sukawana. Sampel subjek diambil sejumlah 88 orang yang ditentukan dengan random sampling. 
Data yang dibutuhkan dalam penelitian ini adalah data primer yaitu, pengetahuan masyarakat tentang bencana tanah longsor dan kesiapsiagaan masyarakat terhadap bencana tanah longsor. Data sekunder, yaitu data fisiografis dan data kependudukan pada wilayah penelitian. Teknik Pengumpulan data dalam penelitian ini menggunakan metode observasi, wawancara dan studi putaka yang selanjutnya dianalisis menggunakan metode deskriptif dengan analisis kualitatif dan kuantitatif.

Data yang berkaitan dengan pengetahuan masyarakat tentang bencana tanah longsor dan kesiapsiagaan masyarakat terhadap bencana tanah longsor di Desa Sukawana dianalisis menggunakan metode analisis deskriptif kualitatif dengan angka rata-rata dan presentase. Sementara data mengenai hubungan antara pengetahuan masyarakat tentang bencana tanah longsor dengan kesiapsiagaan masyarakat dalam menghadapi bencana tanah longsor dianalisis menggunakan metode analisis kuantitatif. Kedua data tersebut memiliki skala interval, sehingga metode analisis yang digunakan adalah dengan analisis korelasi Product Moment. Korelasi Product Moment adalah analisis bivariant yang digunakan untuk menganalisis hubungan antara dua variabel jika data kedua variabel adalah gejala interval atau rasio.

\section{Hasil dan pembahasan}

\section{Pengetahuan Masyarakat Tentang Bencana Tanah Longsor}

Pengetahuan tentang bencana tanah longsor merupakan pemahaman yang dimiliki manusia tentang keadaan yang memiliki potensi terjadinya bencana tanah longsor disuatu wilayah. Secara umum hasil pengetahuan masyarakat tentang bencana tanah longsor di Desa Sukawana terkategori sedang yaitu sebanyak 45 responden atau 51\% dari total 88 responden. Hasil ini sejalan dengan penelitian yang dilakukan oleh Rahmi, 2014 yang meneliti kesiapsiagaan masyarakat terhadap bencana longsor di Kecamatan Linge Kabupaten Aceh Tengah, hasil penelitiannya menunjukkan bahwa pengetahuan masyarakat tentang bencana tanah longsor terkategori sedang sejumlah 42 responden (55\%) dari total 76 responden. Penelitian lain dilakukan oleh Juhadi, Setyaningsih, \& Kurniasari (2016), yang meneliti pola perilaku masyarakat dalam pengurangan resiko bencana tanah longsor di Kecamatan Banjarwangu. Hasil penelitiannya menunjukkan bahwa tingkat pengetahuan masyarakat tentang bencana tanah longsor termasuk kategori sedang sejumlah 41 responden $(41,10 \%)$ dari total 90 responden. Hasil penelitian terhadap pengetahuan masyarkat tentang bencana tanah longsor di Desa Sukawana dapat dilihat pada Tabel 2.

Tabel 2. Hasil Pengetahuan Masyarakat Tentang Bencana Tanah Longsor di Desa Sukawana

\begin{tabular}{|c|c|c|c|c|c|c|c|c|c|}
\hline \multirow[t]{3}{*}{ No } & \multirow[t]{3}{*}{ Nama Dusun } & \multicolumn{6}{|c|}{$\begin{array}{c}\text { Pengetahuan Masyarakat Tentang } \\
\text { Bencana Tanah Longsor }\end{array}$} & \multirow{2}{*}{\multicolumn{2}{|c|}{ Jumlah }} \\
\hline & & \multicolumn{2}{|c|}{ Kurang } & \multicolumn{2}{|c|}{ Sedang } & \multicolumn{2}{|c|}{ Baik } & & \\
\hline & & $\mathrm{N}$ & $\%$ & $\mathrm{~N}$ & $\%$ & $\mathrm{~N}$ & $\%$ & $\mathrm{~N}$ & $\%$ \\
\hline (1) & (2) & (3) & (5) & (6) & (7) & (8) & (9) & (10) & (11) \\
\hline 1. & Kubu Salya & 7 & 44 & 8 & 50 & 1 & 6 & 16 & 100 \\
\hline 2. & Kuta Dalem & 14 & 47 & 14 & 47 & 2 & 6 & 30 & 100 \\
\hline 3. & Lateng & 7 & 50 & 6 & 50 & 1 & 7 & 14 & 100 \\
\hline 4. & Sukawana & 8 & 28 & 17 & 61 & 3 & 11 & 28 & 100 \\
\hline & Jumlah & 36 & 41 & 45 & 51 & 7 & 8 & 88 & 100 \\
\hline
\end{tabular}

Tabel 2 menunjukkan bahwa secara keseluruhan pengetahuan masyarakat tentang bencana tanah longsor di Desa Sukawana berada pada kategori sedang sebanyak 45 responden atau 51\%, sedangkan pengetahuan masyarakat tentang bencana tanah longsor yang berkategori kurang terdapat sebanyak 36 responden atau 41\% dan pengetahuan masyarakat tentang bencana tanah longsor yang berkategori baik terdapat sebanyak 7 responden atau 8\%. Berikut ini disajikan 
pengetahuan masyarakat tentang bencana tanah longsor berdasarkan 5 (lima) indikator yakni pengertian tanah longsor, faktor penyebab tanah longsor, tempat terjadi tanah longsor, waktu terjadi tanah longsor, dan dampak bencana tanah longsor.

Secara umum pengetahuan masyarakat tentang pengertian tanah longsor di Desa Sukawana terkategori rendah, hal ini disebabkan karena rendahnya tingkat pendidikan masyarakat yang mayoritas tamatan sekolah dasar. Dusu dengan pengetahuan terendah yaitu Dusun Lateng karena masyarakatnya belum mengetahui pengertian tanah longsor, yang mereka ketahui tanah longsor adalah pergerakan kerak bumi, sedangkan dusun dengan pengetahuan tertinggi yaitu Dusun Kubu Salya karena masyarakatnya sudah mengetahui tanah longsor adalah pergerakan suatu material tanah menuruni lereng. Pengetahuan masyarakat tentang faktor penyebab tanah longsor di Desa Sukawana terkategori tinggi, hal ini disebabkan karena mayoritas masyarakat di Desa Sukawana tergolong usia produktif yang memiliki banyak pengalaman tentang bencana. Dusun dengan pengetahuan tertinggi yaitu Dusun Sukawana karena masyarakatnya sudah mengetahui faktor penyebab tanah longsor adalah curah hujan tinggi. Sedangkan dusun dengan pengetahuan terendah yaitu Dusun Kubu Salya karena masyarakatnya belum mengetahui faktor penyebab tanah longsor, yang mereka ketahui tanah longsor disebabkan oleh musim kemarau berkepanjangan. Pengetahuan masyarakat tentang waktu terjadi tanah longsor di Desa Sukawana terkategori tinggi, hal ini disebabkan karena mayoritas masyarakat di Desa Sukawana tergolong usia produktif yang memiliki banyak pengalaman tentang bencana. Dusun dengan pengetahuan tertinggi yaitu yaitu Dusun Sukawana karena masyarakatnya sudah mengetahui waktu terjadi tanah longsor ketika musim hujan, sedangkan dusun dengan kategori rendah yaitu Dusun Kubu Salya karena masyarakatnya belum mengetahui waktu terjadi tanah longor, yang mereka ketahui tanah longsor terjadi ketika musim kemarau.

Secara umum pengetahuan masyarakat tentang tempat terjadi tanah longsor terkategori sedang yaitu tanah longsor biasanya terjadi di daerah pegunungan, hal ini disebabkan karena tempat tinggal mereka merupakan daerah pegunung yang rawan longsor. Dusun dengan pengetahuan tertinggi yaitu yaitu Dusun Sukawana karena masyarakatnya sudah mengetahui tanah longsor biasanya terjadi di daerah perbukitan, sedangkan dusun dengan kategori rendah yaitu Dusun Kuta Dalem karena masyarakatnya belum mengetahui tempat terjadi tanah longsor, yang mereka ketahui tanah longsor terjadi di dataran landai. Pengetahuan masyarakat tentang dampak bencana tanah longsor di Desa Sukawana terkategori rendah, hal ini disebabkan karena rendahnya tingkat pendidikan masyarakat yang mayoritas tamatan sekolah dasar sehingga kurang memahami dampak besar bencana tanah longsor. Dusun dengan pengetahuan terendah yaitu Dusun Lateng karena masyarakatnya belum mengetahui dampak bencana tanah longsor, yang mereka ketahui tanah longsor berdampak pada meningkatnya angka kemiskinan, sedangkan dusun dengan pengetahuan tertinggi yaitu Dusun Kubu Salya karena masyarakatnya sudah mengetahui tanah longsor berdampak pada kerugian fisik dan kerusakan ekosistem lingkungan.

Berdasakan hasil penelitian pengetahuan masyarakat tentang bencana tanah longsor di Desa Sukawana terkategori sedang. Namun jika dilihat dari rata-rata skor yang diperoleh masingmasing dusun cukup bervariasi hal tersebut dipengaruhi oleh kondisi demografis yaitu karakteristik responden, yang ditinjau dari dari tingkat pendidikan dan umur penduduk. Tingkat pendidikan mempengaruhi pengetahuan masyarakat. Semakin tinggi tingkat pendidikan maka semakin tinggi pula pengetahuan yang dimiliki. Hasil penelitian menunjukkan tingkat pendidikan masyarakat di Desa Sukawana lebih banyak tamatan SD sebanyak $40 \%$ dengan pendidikan yang terkategori relatif rendah. Selain itu faktor usia juga mempengaruhi tingkat pengetahuan masyarakat, semakin bertambah usia maka tingkat pengetahuan masyarakat akan semakin bertambah. Hasil penelitian menunjukkan usia masyarakat di Desa Sukawana paling banyak adalah usia 40-44 tahun sebanyak $29 \%$, usia yang tergolong produktif. Berikut ini merupakan peta pengetahuan masyarakat tentang bencana tanah longsor di Desa Sukawana, dapat dilihat pada Gambar 1. 


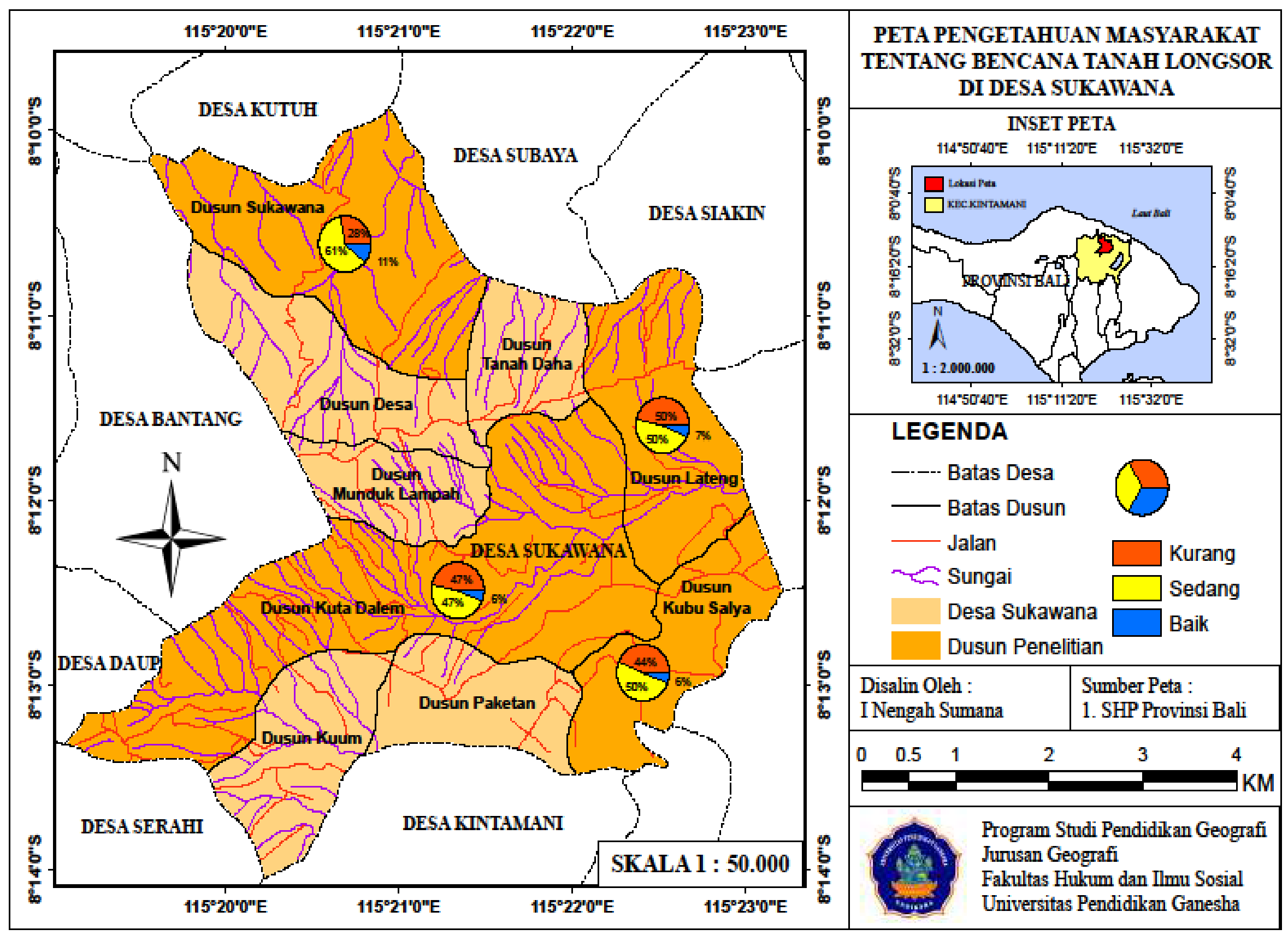


Berdasarkan Gambar 1 menunjukan bahwa dari ke empat dusun yang dijadikan sampel penelitian mempunyai skor yang bervariasi dengan rata-rata tingkat pengetahuan yang terkategori sedang. Dusun dengan kategori kurang tertinggi yaitu dusun Lateng, hal ini dapat dipengaruhi oleh rendahnya pendidikan masyarakat di Dusun Lateng yang mayoritas tamatan sekolah dasar sebanyak 57\%, sehingga kurang mengetahai pengertian sampai dampak becana tanah longsor, sedangkan dusun dengan kategori baik tertinggi yaitu Dusun Sukawana, hal ini dapat dipengaruhi oleh mayoritas masyarakat Dusun Sukawana yang memiliki banyak pengalaman tentang bencana tanah longsor sebanyak 39\%, sehingga mereka sudah belajar dari kejadian-kajian tanah longsor yang mereka alami sebelumnya.

\section{Kesiapsiagaan Masyarakat Terhadap Bencana Tanah Longsor}

Kesiapsiagaan adalah tindakan yang dilakukan untuk mengantisipasi kemungkinan terjadinya bencana melalui pengorganisasian dan langkah yang tepat guna. Secara umum kesiapsiagaan masyarakat terhadap bencana tanah longsor di Desa Sukawana terkategori kurang siap yaitu sebanyak 51 responden (58\%) dari total 88 responden. Hasil ini sejalan dengan penelitian yang dilakukan oleh Retningsih (2018) yang meneliti kesiapsiagaan masyarakat dalam menghadapi bencana tanah longsor di Kecamatan Kaligesing Kabupaten Purworejo, hasil penelitiannya menunjukkan bahwa sebagian besar responden terkategori kurang siap sejumlah 43 reponden $(45,56 \%)$ dari total 94 responden. Penelitian lain dilakukan oleh Firmansyah, Rasni \& Rondhianto (2014) yang meneliti hubungan pengetahuan dengan perilaku kesiapsiagaan dalam menghadapi bencana banjir dan tanah longsor pada remaja usia 15-18 tahun di SMA Al-Hasan Kemiri Kecamatan Panti Kabupaten Jember, hasil penelitiannya menunjukkan bahwa sebagian besar responden terkategori kurang siap sejumlah 46 siswa $(36,8 \%)$ dari total 125 responden seperti terlihat pada Tabel 3.

Tabel 3. Hasil Kesiapsiagaan Masyarakat Terhadap Bencana Tanah Longsor di Desa Sukawana

\begin{tabular}{|c|c|c|c|c|c|c|c|c|c|c|c|c|c|}
\hline \multirow[t]{3}{*}{ No } & \multirow[t]{3}{*}{ Nama Dusun } & \multicolumn{10}{|c|}{ Kesiapsiagaan Masyarakat Terhadap Bencana Tanah Longsor } & \multicolumn{2}{|c|}{ Jumlah } \\
\hline & & \multicolumn{2}{|c|}{$\begin{array}{l}\text { Belum } \\
\text { Siap }\end{array}$} & \multicolumn{2}{|c|}{$\begin{array}{c}\text { Kurang } \\
\text { Siap }\end{array}$} & \multicolumn{2}{|c|}{$\begin{array}{c}\text { Cukup } \\
\text { Siap }\end{array}$} & \multicolumn{2}{|c|}{ Siap } & \multicolumn{2}{|c|}{$\begin{array}{c}\text { Sangat } \\
\text { Siap }\end{array}$} & \multirow[b]{2}{*}{$\mathrm{N}$} & \multirow[b]{2}{*}{$\%$} \\
\hline & & $\mathrm{N}$ & $\%$ & $\mathrm{~N}$ & $\%$ & $\mathrm{~N}$ & $\%$ & $\mathrm{~N}$ & $\%$ & $\mathrm{~N}$ & $\%$ & & \\
\hline (1) & (2) & (3) & (5) & (6) & (7) & (8) & (9) & (10) & (11) & (12) & (13) & (10) & (11) \\
\hline 1. & Kubu Salya & 1 & 6 & 11 & 69 & 3 & 19 & 1 & 6 & - & - & 16 & 100 \\
\hline 2. & Kuta Dalem & 11 & 37 & 16 & 53 & 3 & 10 & - & - & - & - & 30 & 100 \\
\hline 3. & Lateng & 6 & 43 & 7 & 50 & 1 & 7 & - & - & - & - & 14 & 100 \\
\hline 4. & Sukawana & 5 & 18 & 17 & 61 & 4 & 14 & 2 & 7 & - & - & 28 & 100 \\
\hline & Jumlah & 23 & 26 & 51 & 58 & 11 & 13 & 3 & 3 & - & - & 88 & 100 \\
\hline
\end{tabular}

Tabel 3 menunjukkan bahwa secara keseluruhan kesiapsiagaan masyarakat terhadap bencana tanah longsor di Desa Sukawana berada pada kategori kurang siap sebanyak 51 responden atau 58\%, kesiapsiagaan masyarakat terhadap bencana tanah longsor yang berkategori belum siap terdapat sebanyak 23 responden atau $26 \%$, kesiapsiagaan masyarakat terhadap bencana tanah longsor berkategori cukup siap terdapat sebanyak 11 responden atau 13\%, kesiapsiagaan masyarakat terhadap bencana tanah longsor berkategori siap terdapat sebanyak 3 responden atau 3\% dan tidak ada kesiapsiagaan masyarakat terhadap bencana tanah longsor berkategori sangat siap. 
Pengukuran kesiapsiagaan masyarakat terhadap bencana tanah longsor dalam penelitian ini menggunakan empat indikator yakni kebijakan atau panduan keluarga, rencana tanggap darurat, sistem peringatan bencana, dan mobilisasi sumber daya

Kebijakan/paduan keluarga untuk kesiapsiagaan merupakan upaya konkrit untuk melaksanakan kegiatan siaga bencana yang dapat ditinjau dari sub indikator adanya kesepakatan keluarga mengenai tempat evakuasi bencana tanah longsor, hal ini penting agar anggota keluarga khusunya penghuni rumah mengetahui jalur aman untuk dilewati saat kondisi darurat bencana agar sampai ke tempat evakusi. Secara umum kesepakatan keluarga mengenai tempat evakuasi jika terjadi bencana tanah longsor di Desa Sukawana terkategori rendah. Dusun dengan kesepakatan keluarga kategori terendah yaitu Dusun Lateng karena masyarakatnya tidak memiliki kesepakatan keluarga mengenai tempat evakuasi, sedangkan dusun dengan kesepakatan keluarga kategori tertinggi yaitu Dusun Sukawana karena masyarakatnya sudah memiliki kesepakatan keluarga mengenai tempat evakuasi.

Rencana tanggap darurat merupakan upaya krusial untuk mengurangi kerugian yang mungkin terjadi terutama pada saat terjadi bencana dan hari-hari pertama setelah bencana sebelum bantuan dari pemerintah/pihak luar datang yang dapat ditinjau dari beberapa sub indikator sebagai berikut.

\section{1) Rencana penyelamatan keluarga dan recana keluarga mengenai tempat evakuasi}

Secara umum rencana penyelamatan keluarga jika terjadi tanah longsor di Desa Sukawana terkategori rendah yaitu tidak adanya rencana penyelamatan keluarga. Dusun yang terkategori tinggi yaitu Dusun Kubu Salya karena masyaraktnya sudah merencanakan penyelamatan keluarga, mereka sudah membagi tugas permasing-masing anggota keluarga jika terjadi tanah longsor, sedangkan dusun yang terkategori rendah yaitu Dusun Lateng karena masyaraktnya tidak merencanakan penyelamatan keluarga mereka akan melakukan tindakan yang spontanitas saat terjadi bencana, rencana penyelamatan keluarga untuk merespon keadaan darurat penting di rencanakan agar anggota keluarga dapat mengetahui apa yang harus dilakukan saat kondisi darurat bencana. Dalam rencana keluarga mengenai tempat evakuasi di Desa Sukawana secara umum terkategori sedang yaitu masyarakat akan memilih mengungsi ke pengungsian umum yang disediakan oleh pemerintah secara bersamasama. Dusun yang terkategori tinggi yaitu Dusun Kubu Salya karena masyarakatnya memilih mengungsi ke sanak saudara mereka sendiri yang jauh dari bencana tanah longsor, sedangkan dusun yang terkategori rendah yaitu Dusun Lateng karena masyarakatnya memilih mengungsi ke orang lain, kesepakatan dalam keluarga mengenai tempat evakuasi jika terjadi tanah longsor penting dilakukan agar anggota keluarga khusunya penghuni rumah tidak terpencar/dapat berkumpul kembali di tempat pengungsian.

\section{2) Ketersedian obat-obatan penting untuk pertolongan pertama keluarga dan kebutuhan dasar untuk keadaan darurat}

Secara umum ketersedian obat-obatan penting untuk pertolongan pertama keluarga di Desa Sukawana terkategori rendah yaitu masyarakat tidak memiliki obat-obatan/P3K di rumah masing-masing. Dusun yang terkategori tinggi yaitu Dusun Kubu Salya karena masyarakatnya sudah memiliki obat-obatan penting seperti betadin, minyak gosok, dan perban sebagai obat pribadi yang umum dipakai, sedangkan dusun yang terkategori rendah yaitu Dusun Sukawana karena masyarakatnya tidak memiliki obat-obatan penting/P3K, menyediakan obat-obatan penting/P3K di rumah masing-masing penting agar jika terjadi bencana pertolongan pertama keluarga untuk mengobati korban luka dapat diberikan secara cepat. Dalam kebutuhan dasar masyarakat untuk keadaan darurat secara umum berada pada kategori sedang yaitu masyarakat belum mempersiapkan kebutuhan dasar untuk keadaan darurat bencana, seperti makanan, minuman, senter dan baterai. Dusun dengan kategori 
tinggi yaitu Dusun Kubu Salya karena masyarakatnya sudah mempersiapkan kebutuhan dasar untuk keadaan darurat, seperti makanan siap saji, minuman dalam kemasan dan senter, sedangkan dusun dengan kategori rendah yaitu Dusun Kubu Salya karena masyarakanya tidak mempersiapkan kebutuhan dasar untuk keadaan darurat, menyediakan kebutuhan dasar untuk keadaan darurat di rumah masing-masing penting dilakukan karena bencana dapat terjadi secara tiba-tiba hal ini bertujuan agar jika terjadi bencana kebutuhan dasar masyarakat yang terkena bencana dapat terpenuhi untuk sementara.

\section{3) Ketersediaan alat komunikasi dan fasilitas-fasilitas penting yang memiliki akses dengan bencana}

Secara umum ketersediaan alat komunikasi di Desa Sukawana terkategori tinggi yaitu masyarakat sudah memiliki alat komunikasi alternatif. Dusun yang terkategori tinggi yaitu dusun Sukawana karena masyarakatnya sudah memiliki alat komunikasi hanphone, sedangkan dusun yang terkategori rendah yaitu Dusun Kuta Dalem karena masyarakatnya tidak memiliki alat komunikasi alternatif, seperti hanphone atau HT. Banyaknya masyarakat yang memiliki alat komunikasi hanphone tidak diimbangi dengan ketersediaan masyarakat yang menyimpan nomor telepon instansi terkait bencana, hal ini dibuktikan dengan ketersediaan fasilitas-fasilitas penting yang memiliki akses dengan bencana berada dalam kategori rendah, yang artinya sedikitnya masyarakat yang memiliki nomor telepon instansi terkait bencana. Dusun yang terkategori tinggi yaitu dusun Lateng karena masyarakatnya memiliki nomor telepon rumah sakit dan polisi, sedangkan dusun yang terkategori rendah yaitu dusun Kuta Dalem karena masyarakatnya tidak memiliki nomor telepon rumah sakit/polisi/BPBD/Pemadam kebakaran/PAM/PLN /Telkom, ketersediaan alat komunikasi penting dimiliki oleh masyarakat di Desa Sukawana guna menunjang informasi terkait bencana.

\section{4) Latihan/simulasi kesiapsiagaan bencana}

Secara umum latihan/simulasi kesiapsiagaan bencana di Desa Sukawana terkategori rendah yaitu seluruh responden (88responden) belum pernah mendapatkan latihan dan simulasi kesiapsiagaan bencana. Rendahnya latihan/simulasi kesiapsiagaan bencana di daerah penelitian tidak terlepas dari kurangnya pelatihan/simulasi terkait bencana yang dilakukan oleh pemerintah.

Sistem peringatan bencana merupakan serangkaian sistem yang berfungsi untuk memberikan informasi pada msayarakat dalam keadaan kritis akan terjadinya bencana yang dapat dilihat dari sub indikator ketersediaan teknologi/sumber informasi peringatan bencana dan sumber informasi kebencanaan yang diperoleh masyarakat, hal ini penting untuk mengurangi resiko dan menambah wawasan masyarakat akan bencana. Secara umum ketersediaan teknologi/sumber informasi peringatan bencana di Desa Sukawana berada pada kategori rendah, rendahnya ketersediaan teknologi/sumber informasi peringatan bencana disebabkan karena di Desa Sukawana tidak ada sumber informasi peringatan bencana berbasis teknologi seperti sirine/alaram pendeteksi gejala tanah longsor. Dalam sumber informasi kebencanaan yang diperoleh masyarakat secara umum berada pada kategori sedang yaitu sumber informasi yang diperoleh masyarakat melalui televisi ataupun media sosial, sedangkan dusun yang terkategori rendah yaitu Dusun Lateng karena masyarakatnya tidak pernah mendengar informasi kebencanaan baik itu dari media sosial maupun sosialisasi pemerintah.

\section{d. Mobilitas Sumber Daya}

Mobilisasi sumber daya merupakan upaya yang krusial untuk meningkatkan kesiapsiagaan bencana yang dapat ditinjau dari sub indikator keterlibatan anggota keluarga dalam pertemuan seminar/pelatihan kesiapsiagaan bencana dan adanya alokasi 
dana/tabungan keluarga untuk menghadapi bencana. Secara umum keterlibatan anggota keluarga dalam pertemuan seminar/pelatihan kesiapsiagaan bencana berada pada kategori rendah yaitu tidak adanya anggota keluarga dalam masyarakat yang ikut/terlibat dalam pertemuan seminar/pelatihan kesiapsiagaan bencana, hal ini disebabkan karena di Desa Sukawana sendiri belum pernah diadakan pertemuan seminar/pelatihan kesiapsiagaan bencana oleh pemerintah atau instansi terkait, sedangkan dusun yang terkategori tinggi yaitu Dusun Sukawana karena ada anggota keluarga dalam masyarakat yang sempat mengikuti pertemuan seminar tentang bencana di luar Desa Sukawana. Jika dilihat dari alokasi dana/tabungan keluarga untuk menghadapi bencana secara umum berada pada kategori rendah, sedangkan dusun yang terkategori tinggi yaitu dusun Sukawana karena masyarakatnya memiliki tabungan keluarga untuk menghadapi bencana dengan jumlah $>5000.000$, dan dusun yang terkategori rendah yaitu dusun Lateng karena masyarakatnya tidak memiliki dana/tabungan keluarga untuk menghadapi bencana. Rendahnya dana/tabungan keluarga dapat disebabkan karena mayoritas masyarakat Desa Sukawana bekerja pada sektor pertanian yang penghasilan perbulannya tidak menentu.

Berdasakan hasil penelitian kesiapsiagaan masyarakat terhadap bencana tanah longsor di Desa Sukawana terkategori kurang siap. Namun jika dilihat dari rata-rata skor yang diperoleh masing-masing dusun cukup bervariasi hal tersebut dipengaruhi oleh kondisi demografis yaitu karakteristik responden, yang ditinjau dari tingkat pendidikan, pekerjaan dan usia responden. Tingkat pendidikan mempengaruhi kesiapsiagaan masyarakat. Semakin tinggi tingkat pendidikan maka semakin tinggi pula kesiapsiagaan yang dimiliki. Hasil penelitian menunjukkan tingkat pendidikan masyarakat di Desa Sukawana lebih banyak tamatan SD sebanyak $40 \%$ dengan pendidikan yang terkategori relatif rendah, selain itu faktor pekerjaan mempengaruhi tingkat kesiapsiagaan masyarakat karena pekerjaan berhubungan dengan pendapatan masyarakat, semakin tinggi pendapatan dari pekerjaan masyarakat maka tingkat kesiapsiagaannya akan semakin tinggi. Hasil penelitian menunjukan pekerjaan masyarakat di Desa Sukawana rata-rata bekerja pada sektor pertanian sebanyak 69 $\%$, dengan pendapatan perbulannya tidak mementu dan faktor usia juga mempengaruhi tingkat kesiapsiagaan masyarakat, semakin bertambah usia maka tingkat kesiapsiagaan masyarakat akan semakin bertambah. Hasil penelitian menunjukkan usia masyarakat di Desa Sukawana paling banyak adalah usia 40-44 tahun sebanyak $29 \%$, usia yang tergolong produktif. Berikut ini merupakan peta penyajian data kesiapsiagaan masyarakat terhadap bencana tanah longsor di Desa Sukawana, dapat dilihat pada Gambar 2.

Berdasarkan Gambar 2 menunjukan bahwa dari ke empat dusun yang dijadikan sampel penelitian mempunyai skor yang bervarisai dengan rata-rata tingkat kesiapsiagaan dalam kategori kurang siap. Dusun dengan kategori belum siap yaitu Dusun Lateng, hal ini dapat dipengaruhi oleh rendahnya pendidikan masyarakat di Dusun Lateng yang mayoritas tamatan sekolah dasar sebanyak $57 \%$ dan bekerja dalam bidang pertanian atau sebagai petani sebanyak $86 \%$, yang dikonotasikan identik dengan keterbelakangan, hal ini dibuktikan dengan rendahnya tabungan/alokasi dana untuk bencana di Dusun Lateng, sedangkan dusun dengan kategori siap yaitu Dusun Sukawana, hal ini dapat dipengaruhi oleh mayoritas masyarakat Dusun Sukawana yang berusia 40-49 tahun sebanyak 78 \%, sehingga sudah memiliki banyak pengalaman menghadapi bencana tanah longsor. 


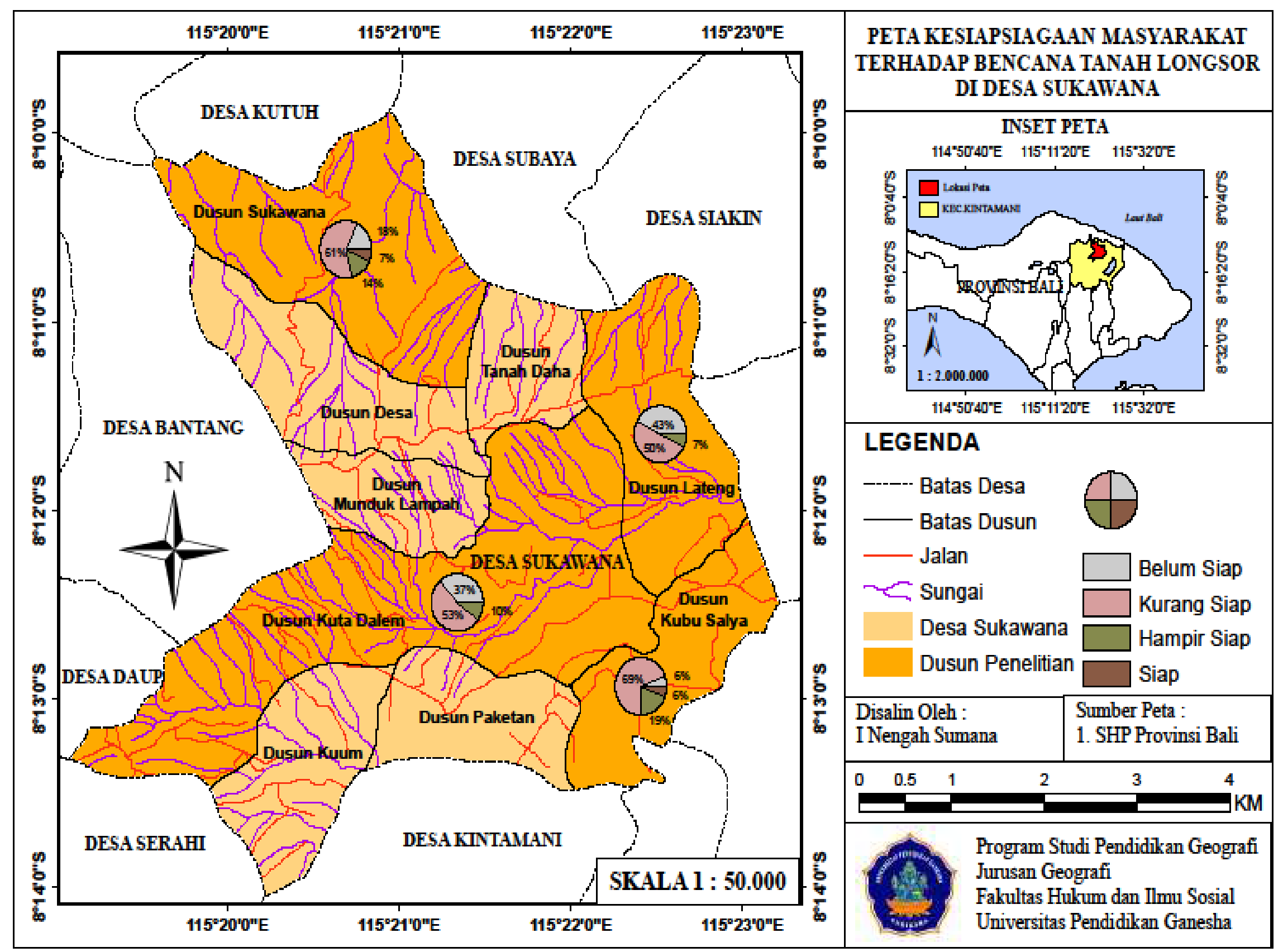





\section{Hubungan Pengetahuan Masyarakat Tentang Bencana Tanah Longsor Dengan Kesiapsiagaan Masyaraat Terhadap Bencana Tanah Longsor}

Pengetahuan merupakan pemahaman yang dimiliki tentang sesuatu sedangkan kesiapsiagaan merupakan tindakan-tindakan yang dilakukan untuk mampu menanggapi suatu situasi. Pengetahuan masyarakat tentang bencana tanah longsor secara umum terkategori sedang (51\%). Kesiapsiagaan masyarakat terhadap bencana tanah longsor di Desa Sukawana secara umum terkategori kurang siap (58\%).

Hasil perhitungan dengan IBM SPSS Statistics 25 diperoleh hasil koefisiensi korelasi terlihat pada Tabel 4.

Tabel 4. Ringkasan Hasil Analisis Korelasi

Antara Variabel Pengetahuan (X) dan Kesiapsiagaan (Y)

\begin{tabular}{|c|c|c|c|}
\hline \multicolumn{4}{|l|}{ Correlations } \\
\hline & & Pengetahuan & Kesiapsiagaan \\
\hline \multirow[t]{3}{*}{ Pengetahuan } & Pearson Correlation & 1 & ,228* \\
\hline & Sig. (2-tailed) & & ,033 \\
\hline & $\mathrm{N}$ & 88 & 88 \\
\hline \multirow[t]{3}{*}{ Kesiapsiagaan } & Pearson Correlation & ,228* & 1 \\
\hline & Sig. (2-tailed) & ,033 & \\
\hline & $\mathrm{N}$ & 88 & 88 \\
\hline
\end{tabular}

*.Correlation is significant at the 0.05 level (2-tailed).

Berdasarkan Tabel 4. Dapat diketahui bahwa responden sebanyak 88 dihasilkan korelasi senilai 0,228 . Terdapat atau tidaknya korelasi antara pengetahuan masyarakat tentang bencana tanah longsor dengan kesiapsiagaan masyarakat terhadap bencana tanah longsor akan dibuktikan dengan cara mengkoreksi variabel secara kuantitatif. Hipotesis yang dibuat menyatakan bahwa pengetahuan mempengaruhi tindakan-tindakan kesiapsiagaan. Sehingga semakin tinggi pengetahuan masyarakat tentang bencana tanah longsor semakin tinggi pula kesiapsiagaan masyarakat terhadap bencana tanah longsor. Sebelum melakukan pengujian, hipotesis yang diajukan dalam penelitian ini dirumuskan sebagai berikut.

Ho : Pengetahuan masyarakat tetang bencana tanah longsor memiliki hubungan negatif terhadap kesiapsiagaan masyarakat terhadap bencana tanah longsor di Desa Sukawana.

$\mathrm{Ha}$ : Pengetahuan masyarakat tentang bencana tanah longsor memiliki hubungan positif terhadap kesiapsiagaan masyarakat terhadap bencana tanah longsor di Desa Sukawana.

Hasil koefisiensi korelasinya signifikan atau tidak, maka akan dibandingkan dengan $r$ tabel dengan taraf kesalahan tertentu. Memperhatikan $\mathrm{r}$ tabel Product Moment dengan taraf kesalahan 5\% (taraf kepercayaan 95\%) dan $\mathrm{N}=88$, maka harga $r$ tabel adalah 0,207. Ternyata $r$ hitung $(0,228)$ lebih besar dibandingkan dengan $r$ tabel $(0,207)$ sehingga Ho ditolak dan Ha diterima. Sehingga pengetahuan masyarakat tentang bencana tanah longsor memiliki hubungan positif dengan kesiapsiagaan terhadap bencana tanah longsor di Desa Sukawana.

Memberikan penafsiran terhadap koefisien korelasi yang ditentukan tersebut besar atau kecil, maka dapat berpedoman pada pedoman interpretasi korelasi menurut Sugiono (2010:231) dapat dilihat pada Tabel 5.

Tabel 5. Pedoman Interpretasi Terhadap Koefisien Korelasi

\begin{tabular}{lll}
\hline No. & Interval Koefisien & Tingkat Hubungan \\
\hline$(1)$ & $(2)$ & $(3)$ \\
\hline 1 & $0,20-0,399$ & Rendah \\
\hline 2 & $0,40-0,599$ & Sedang \\
\hline 3 & $0,60-0,799$ & Kuat \\
\hline 4 & $0,80-1,000$ & Sangat Kuat \\
\hline
\end{tabular}

Sumber: Sugiono (2010:231) 
Berdasarkan Tabel 5 maka tingkat hubungan antara pengetahuan masyarakat tentang bencana tanah longsor dengan kesiapsiagaan masyarakat terhadap bencana tanah longsor adalah rendah $(0,228)$.

Hasil penelitian ini sejalan dengan penelitian yang dilakukan oleh Mas'Ula, Sriartha, \& Citra (2019) yang meneliti tentang hubungan antara pengetahuan dan kesiapsiagaan masyarakat terhadap bencana banjir di Desa Pancasari. Hasil penelitiannya menunjukan terdapat hubungan antara pengetahuan dan kesiapsiagaan masyarakat terhadap bencana banjir di Desa Pancasari. Tingkat hubungannya adalah rendah atau 0,255. Penelitian lain dilakukan oleh Pradiastuti (2014) yang meneliti mengenai hubungan pengetahuan dan kesiapsiagaan terhadap bencana banjir pada siswa kelas 7 SMP Negeri 3 Mojolaban Kabupaten Sukoharjo. Hasil penelitian menunjukkan ada hubungan pengetahuan dengan kesiapsiagaan terhadap bencana banjir pada siswa kelas 7 SMP Negeri 3 Mojolaban Kabupaten Sukoharjo. Hubungan pengetahuan dengan kesiapsiagaan terhadap bencana banjir menunjukkan hubungan yang berpola positif namun kekuatan hubungannya lemah. Penelitian lain juga dilakukan oleh Luthfiana (2016), yang meneliti mengenai hubungan tingkat pengetahuan kebencanaan dengan peran serta masyarakat dalam mengurangi risiko bencana tanah longsor di Kecamatan Gunungpati Kota Semarang, hasil penelitian diperoleh angka koefisien sebesar 0,185. Hubungan pengetahuan dengan peran serta masyarakat dalam mengurangi risiko bencana tanah longsor di Kecamatan Gunungpati Kota Semarang, menunjukkan adanya hubungan yang berpola positif namun kekuatan hubungannya lemah. Artinya semakin tinggi pengetahuan tidak selalu diimbangi dengan semakin tingginya perilaku kesiapsiagaan.

Pengetahuan merupakan faktor utama dan menjadi kunci untuk kesiapsiagaan. Pengetahuan yang dimiliki biasanya dapat mempengaruhi kepedulian masyarakat untuk siap dan siaga dalam mengantisipasi bencana, terutama bagi masyarakat yang bertempat tinggal di daerah yang sering mengalami bencana seperti Desa Sukawana yang dalam 10 tahun terakhir terjadi bencana tanah longsor, sehingga diperlukan peningkatan pengetahuan masyarakat tentang bencana tanah longsor seperti sosialisasi maupun pelatihan guna meningkatkan kesiapsiagaan masyarakat.

\section{Simpulan dan saran}

Berdasarkan hasil dan pembahasan yang telah diuraikan mengenai kesiapsiagaan masyarakat terhadap bencana Tanah Longsor di Dessa Sukawana, maka diperoleh simpulan sebagai berikut. Pengetahuan masyarakat tentang bencana tanah longsor di Desa Sukawana secara umum terkategori sedang sebanyak $51 \%$, hal ini dapat dipengaruhi oleh rendahnya pendidikan masyarakat di Desa Sukawana yang rata-rata tamatan sekolah dasar dan belum adanya sosialisasi tentang bencana oleh pemerintah. Jika dilihat dari pengetahuan tentang pengertian dan dampak bencana tanah longsor terkategori rendah yaitu tanah longsor adalah pergerakan kerak bumi yang dapat menyebabkan kemisiknan, dan jika dilihat dari faktor penyebab dan waktu terjadi tanah longsor terkategori tinggi yaitu tanah longsor disebabkan oleh curah hujan tinggi yang biasanya terjadi ketika musim hujan, sedangan jika dilihat dari tempat terjadi tanah longsor terategori sedang yaitu tanah longsor biasanya terjadi di daerah pegunungan. Dalam kategori sedang ini artinya masyarakat di Desa Sukawana belum memahami secara komprehensif tentang bencana tanah longsor. Kesiapsiagaan masyarakat terhadap bencana tanah longsor di Desa Sukawana secara umum terkategori kurang siap sebanyak 58 \%. Berdasarkan kebijakan keluarga untuk kesiapsiagaan, masyarakat di Desa Sukawana tidak memiliki kesepakatan keluarga mengenai tempat evakuasi. Untuk keadaan darurat, masyarakat di Desa Sukawana tidak memiliki rencana penyelamatan keluarga, obat-obatan/P3K, kebutuhan dasar untuk keadaan darurat, fasilitas-fasilitas penting yang memiliki akses dengan bencana dan tidak pernah mendapatkan latihan/ simulasi kesiapsiagaan bencana. Dalam sistem peringatan bencana masyarakat di Desa Sukawana mengetahui bencana tanah longsor melalui televisi dan media sosial dikarenakan tidak adanya sirine/alarm untuk pemberitahuan ketika terjadi bencana tanah longsor. Sedangkan dalam mobilitas sumber daya masyarakat di Desa Sukawana tidak menyisihkan dana untuk keadaan darurat dan tidak ada anggota keluarga yang terlibat 
dalam seminar kesiapsiagaan bencana. Hal tersebut yang menyebabkan kesiapsiagaan masyarakat di Desa Sukawana berada dalam kategori kurang siap, dalam kategori kurang siap ini artinya masyarakat di Desa Sukawana akan terancam jika sewaktu-waktu terjadi tanah longsor. Terdapat korelasi positif atau hubungan antara pengetahuan masyarakat tentang bencana tanah longsor dengan kesiapsiagaan masyarakat terhadap bencana tanah longsor di Desa Sukawana.. Tingkat hubungan antara pengetahuan masyarakat dengan kesiapsiagaan masyarakat terhadap bencana tanah longsor adalah rendah atau 0,228.

Berdasarkan pada manfaat penelitian maka saran yang dapat diajukan adalah sebagai berikut. Bagi Masyarakat di Desa Sukawana agar penelitian ini dapat dijadikan acuan informasi mengenai kesiapsiagaan masyarakat terhadap bencana tanah longsor dan diperlukannya peningkatan pengetahuan dan kesiapsiagaan tentang bencana tanah longsor dengan cara membentuk anggota siaga bencana dan terlibat dalam seminar/pelatihan kesiapsiagaan bencana. Bagi Pemerintah Daerah/Kota agar penelitian ini dapat dijadikan acuan sumber informasi mengenai kesiapsiagaan masyarakat terhadap bencana tanah longsor dan Pemerintah Daerah/Kota seharusnya mengadakan mitigasi bencana secara struktural dan non struktural kepada masyarakat di Desa Sukawana. Bagi Peneliti selanjutnya diharapkan agar mengambil sampel lebih banyak, hal ini bertujuan untuk keakuratan data yang lebih baik dalam penelitiannya dan diharapkan adanya tambahan indikator lain, hal ini bertujuan untuk memperbanyak indikator sebagai pengukur pengetahuan dan kesiapsiagaan bencana tanah longsor.

\section{Daftar Rujukan}

Badan Penanggulangan Bencana Daerah Kabupaten Bangli. (2018). Laporan Kejadian dan Dampak Kejadian Bencana di Kabupaten Bangli.

Bappeda Bali dan PPLH UNUD. (2006). Studi Identifikasi Potensi Bencana Alam Di Provinsi Bali. Denpasar : Pusat Penelitan Universitas Udayana.

Dinas Kependudukan dan Pencatatan Sipil Kabupaten Bangli. (2019). Laporan Kependudukan Kecamatan Kintamani Tahun 2016.

Firmansyah, Rasni, \& Rondhianto. (2014). Hubungan Pengetahuan Dengan Perilaku Kesiapsiagaan Dalam Menghadapi Bencana Banjir Dan Longsor Pada Remaja Usia 15-18 Tahun Di SMA Al-Hasan Kemiri Kecamatan Panti Kabupaten Jember. Artikel Ilmiah, 12(1).

Juhadi, Setyaningsih, \& Kurniasari. (2016). Pola Perilaku Masyarakat Dalam Pengurangan Resiko Bencana Tanah Longsor Di Kecamatan Banjarwangu Kabupaten Banjarnegara Jawa Tengah. Jurnal Geografi, 13(2), 217.

LIPI-UNESCO/ISDR. (2006). Kajian Kesiapsiagaan Masyarakat Dalam Mengantisipasi Bencana Gempa Bumi dan Tsunami. Jakarta : Lembaga Ilmu Pengetahuan Indonesia.

Luthfiana, F. R. (2016). Hubungan Tingkat Pengetahuan Kebencanaan Dengan Peran Serta Masyarakat Dalam Mengurangi Risiko Bencana Tanah Longsor di Kecamatan Gunungpati Kota Semarang. Skripsi. Universitas Negeri Semarang.

Mas'Ula, N., Sriartha, I. P., \& Citra, I. P. A. (2019). Kesiapsiagaan Masyarakat Terhadap Bencana Banjir Di Desa Pancasari Kecamatan Sukasada Kabupaten Buleleng. Jurnal Pendidikan Geografi Undiksha, 7(3).

Pemerintah Kabupaten Bangli. (2019). Kondisi Fisik dan Dasar Wilayah. Retrieved from http://banglikab.go.id/index.php/baca-selayang-pandang/14/Kondisi-Fisik-dan-DasarWilayah.html

Pradiastuti, N. (2014). Hubungan Pengetahuan dan Kesiapsiagaan Terhadap Bencana Banjir Pada Siswa Kelas 7 SMP Negeri 3 Mojolaban Kabupaten Sukoharjo. Skripsi. Universitas Muhammadiyah Surakarta.

Pusat Vulkanologi dan Mitigasi Bencana Geologi. (2017). Laporan Singkat Bencana Gerakan Tanah Kecamatan Kintamani, Kabupaten Bangli, Provinsi Bali.

Rahmi, F. (2014). Kajian Kesiapsiagaan Masyarakat Terhadap Bencana Tanah Longsor di Kecamatan Linge Kabupaten Aceh Tengah. Tesis. Universitas Syiah Kuala Darussalam Banda Aceh. 
Retningsih, E. (2018). Kesiapsiagaan Masyarakat Dalam Menghadapi Bencana Tanah Longsor di Kecamatan Kaligesing Kabupaten Purworejo. Skripsi. Universitas Negeri Yogyakarta.

Setyari, F. I. (2012). Pemahaman Masyrakat Terhadap Tingkat Kerentanan Bencana Tanah Longsor di Desa Tieng Kecamatan Kejajar Kabupaten Wonosobo. Skripsi, Jurusan Pendidikan Geografi, Universitas Negeri Yogyakarta.

Suarsana, I Nyoman, D. (2015). Etnografi desa sukawana, kecamatan kintamani, kabupaten bangli, bali. Denpasar : Pusat Penelitan Universitas Udayana.

Sugiono. (2010). Metode Penelitian Kuantitatif Kualitatif R\&D. Bandung: Alfabeta.

Wulan, T. R., Ambarwulan, W., Putra, A. S., Putra, M. D., Maryanto, D., Pinem, F., \& Maulana, E. (2017). Pemetaan Cepat Kawasan Terdampak Bencana Longsor dan Banjir di Kabupaten Bangli, Provinsi Bali. Majalah Geografi Indonesia, 31(2), 44. https://doi.org/10.22146/mgi.26230 